The following Beit Memorial Fellowships for Medical Research have been awarded for work at the places indicated. Fourth Year Fellowships $(£ 1,000)$ : Dr. B. T. Donovan, to study the hypothalamic mechanisms underlying the regulation of the onset of puberty and the mechanisms regulating the onset of ostrus (Institute of Psychiatry, Maudsley Hospital, London); Dr. D. S. H. W. Nicol, to continue his investigations of the chemistry and pharmacology of peptide fractions of insulin (Dunn Institute of Biochemistry, University of Cambridge). Junior Fellowships ( $£ 800$ a year): Dr. G. A. J. Goodlad, to study the effect of the presence of a tumour on the protein metabolism of the host (Department of Biochemistry, University of Glasgow) ; I. Oswald, for human electroencephalographic studies of the role of the emotional significance of conditioned stimuli in determining their arousal value during sleep, and the mechanism of inhibition of responses to them (Institute of Experimental Psychology, Oxford); I. C. Roddie, to study the role of high-and low-pressure receptors of the vascular system in the regulation o the human circulation (Department of Physiology, Queen's University, Belfast) ; Dr. S. Varadarajan, for a comparative study of nucleotide metabolism in cancerous and normal tissue (Department of Radiotherapeutics, University of Cambridge); Dr. Pauline M. Meadow, to study the structure and mode of synthesis of bacterial cell walls, with special reference to their amino-acid and amino-sugar components (Department of Biochemistry, University College, London).

\section{International Conference on Radio-Isotopes in Scientific Research}

AN International Conference on Radio-Isotopes in Scientific Research will be held in Paris during September 9-20. This Conference is being convened by Unesco, after consultation with the United Nations Secretariat and interested specialized agencies, in particular the World Health Organization, the United Nations Food and Agriculture Organization and the World Meteorological Organization. The Conference will be strictly scientific in character. Its purpose is to bring together a large number of specialists in the various scientific disciplines interested in the use of radioisotopes, so that they may submit the results of their research and exchange information and views on a series of subjects in which developments are proceeding at a particularly rapid pace. The working languages of the Conference will be English and French. The records of the Conference will be published. Further information can be obtained from Unesco, Radioisotopes Conference, 19 avenue Kléber, Paris 16.

Safety and Atomic Energy Developments

IN conjunction with the Safety and Factory Efficiency (S.A.F.E.) Exhibition, being held in Birmingham during June 14-21, and with the United Kingdom Atomic Energy Authority, a week. end congress is to be organized to discuss safety and efficiency aspects of atomic energy, under the chairmanship of Dr. P. F. R. Venables. The congress, which is to take place at Bingley Hall, Birmingham, during June 14-16, will include sessions on "Training for Atomics" (I. Hopkins, chief training officer, Industrial Group, United Kingdom Atomic Energy Authority); on "Isotopes in Industry" (Dr. H. Seligman, head of the Isotope Division, Atomic Energy Research Establishment, Harwell); on
"Health and Safety when using Radioactive Materials" (A. S. McLean, chief medical officer, Industrial Group, United Kingdom Atomic Energy Authority); and on "Atomic Reactors" (Dr. J. V. Dunworth, head of the Reactor Division, Atomic Energy Research Establishment, Harwell). Inquiries should be addressed to Mr. W. G. Appleyard, Industrial Safety Training Centre, 22 Summer Road, Acocks Green, Birmingham 27.

\section{Announcements}

THE autumn meeting of the Institute of Metals will be held in Glasgow during September 17-20, by invitation of the Scottish local section.

A MEETING of the Royal Meteorological Society will be held in the Department of Natural Philosophy, University of Glasgow, during July 3-5. The meeting, which is open to all who are interested, without fee, will include sessions on "Cloud Physics" and on "The Problem of Hill Climate". Accommodation may be reserved for members, wives and visitors at Quieen Margaret Hall, Glasgow. Inquiries should be addressed to the Assistant Secretary, Royal Meteorological Society, 49 Cromwell Road, London, S.W.7, not later than June 19.

A Conference organized by the Physical Society on "Materials for Nuclear Engineering" will be held at Associated Electrical Industries, Ltd., Aldermaston, Berkshire, on July 11 and 12. Non-members will be welcome to attend on payment of a conference fee of one guinea. Accommodation will be available in two halls of residence at the University of Reading. Programmes and application forms will be available later and all inquiries should be addressed to the Physical Society, 1 Lowther Gardens, Prince Consort Road, London, S.W.7, marked for the attention of Miss Miles.

THE last date for the submission of applications to the Foundations' Fund for Research in Psychiatry for research fellowships and research teaching grants in psychiatry, psychology, sociology, neurophysiology, and other sciences relevant to mental health, is October 15. Interested persons and departments should write for details to the Foundations' Fund for Research in Psychiatry, 251 Edwards Street, New Haven 11, Connecticut.

THe trustees of the Plastics Industry Education Fund invite applications from young men or women engaged in the plastics industry for a limited number of training grants up to a value of $£ 100$ towards the cost of a year's full-time study at an approved course leading to a degree, diploma or other equivalent qualification in science or engineering, or in industrial design. Approved courses for full-time study include those leading to the associateship of the Plastics Institute, intermediate or final B.Sc., or Dip. Tech. courses in pure and applied mathematics, physics, chemistry or engineering, and diplome courses in chemistry, electrical and mechanical engineering, and industrial design. Applications for Training Grants must be submitted in writing, before July 13, to the Secretary to the Council, Plastica Institute, 6 Mandeville Place, London, W.1, from whom further particulars can be obtained.

IN Nature of May 11, p. 951, the appointment of the Duke of Northumberland as chairman of the Agricultural Research Council was announced; it should have been stated that he takes office on July 1, 1958. 